\title{
How the Babylonians Protected Themselves against Calamities Announced by Omens
}

\author{
Stefan M. Maul
}

The Babylonians believed that they could detect indications of positive or negative future events in both unusual as well as everyday occurrences in the behaviour of animals, the appearance of plants or men, the movements of the stars and the planets, the condition of the sun and the moon, and all manner of metereological phenomena. Thousands of such omens were set down in countless works which drew on observations, experiences, and traditions, which themselves were centuries, perhaps even millennia old. To each omen a meaning was assigned. Now we should not, as Bruno Meissner once did, brand this 'prophetic science' as 'horrible superstition'. For such collections of omens helped to save the individual's future as well as that of the community from the dominion of acts which were uncontrollable, incomprehensible, and thus incapable of being provided against, in brief from the forces of chaos, which the Babylonians feared more than anything else. Omens of all kinds allowed them to extend into the future the certainty of a reality, which for us only the present possesses. The psychological effects which the forecasting of the future had on those who believed must by no means be underestimated: an ill-defined apprehensiveness in the face of the menaces of an uncertain future wherein at its worst one is at the mercy of every chaotic power imaginable, gives way to a delimited fear of a known and hence understandable threat. Such fear can be controlled since it refers to concrete, familiar, perhaps even already experienced events.

Nevertheless, the Babylonians were never so fatalistic as to assume that one could not escape from a disaster portended by a successfully interpreted omen. A portent merely indicates one possibility: the calamity involved - illness, death, accident, or natural disaster - will only occur if one does not take any action against it. A society which sees the universe as the interlocking wheels and springs of an enormous clock that acts upon the future out of the past and beyond the present, and which develops a finely calibrated system of relationships between the future and seemingly insignificant events of the present, will of necessity find the means, once the future has been predicted, to bend the future to its own advantage. While such methods are not attested for Mesopotamia in writing before the first millennium BCE, we nevertheless have every reason to believe that they originated in much earlier times.

The Babylonians called rituals for staving off calamities predicted by omens nam-búr-bi, which translated literally means '(ritual for) releasing therefrom (i.e. from a catastrophe which an omen has predicted, but which has not yet taken place)'.

The clear, consecutive logic of the structure of these rituals reveals itself to us only after we have comprehended the Babylonians' conception of omens and of their effects on the world. Nevertheless, little work has been done along these lines in our field. An example: If a dog constantly howled and yelped in someone's house, this boded evil for the owner of the house and his family. The person affected, however, had more to fear 


\section{Stefan M. Maul}

than impending doom, for the appearance of the hound in his home was - according to the Babylonian view of things - much more than an omen. The sign - in our example a howling $\mathrm{dog}$ - had been sent to the person involved by his personal gods because he had displeased them in some way or other and they wished to punish him. What has hitherto gone unrecognised is that it was the animal itself which threatened the person! Like a spore, the evil (lumnu), which according to the omen would later harm the person, already inhabited the dog and the dog then infected the person and his surroundings by means of the sinister energy that emanated from it. The danger of infection was considered to be so great that the evil (lumnu) penetrated into a person even if he had not touched the dog or animal or object, but had only seen it. In a ritual, in which a person attempts to prevent evil announced by snakes, he prays to the gods that they lumna ina zumrïsunu likillü, ${ }^{1}$ i.e. that they 'keep back the evil in the body (of the snakes)'. The evil emanating from a portent - in our example the howling dog - operated on a person until its sinister power culminated in the calamity which had been predicted in the apodosis of the relevant omen interpretation. The Babylonians termed the growth and development of the danger from the time of infection by the omen until the outbreak of the actual catastrophe - a way of thinking which is, by the way, not unlike our modern concept of the incubation period of a disease - quite aptly the qê lumni, that is to say, 'the thread of evil'. It was the avowed purpose of the namburbi rituals to cut the 'thread of evil'.

If we accept this briefly sketched interpretation of the operation of an omen, then we can formulate the following aims which a 'release ritual' was supposed to achieve:

1) the person affected must placate the anger of the gods who had sent him the omen;

2) the person must effect the gods' revision of their decision to give him an evil fate;

3) the impurity which the person had acquired through the agency of the omen must be removed;

4) the impurity of the person's house and general surroundings must be removed;

5) the person must be returned to his normal, 'intact' life;

6) the person should be provided with permanent protection against the renewed threat of sinister omens.

These six aims correspond exactly to the six constitutive elements of a namburbi ritual, as I now propose to show.

The person wishing to achieve a correction of the fate which the gods have allotted him must appeal to the divine triad Ea, Šamaš, and Asalluhi. Šamaš, the Sun God, is accounted the 'Lord of the Above and Below', he 'Who Sees All', and, in consequence, 'Judge of Heaven and Earth'2, since he travels by day over all the Earth and by night journeys through the regions beneath it. As the one who constantly and routinely circles the Earth, Šamaš is the most striking element of dynamic order. For this reason he is reckoned to be the Guardian and Watchman of Creation; he sees to it that the universe in the same manner as the sun - continues to move in its proper course. This role of the Sun God as paragon and guardian is expressed in the epithet muštešsiru, he 'Who Guides Aright', an epithet which often appears in the namburbi-prayers. Šamaš is supposed to

1 Cf. S.M. Maul, Zukunftsbewältigung (Mainz am Rhein, 1994), 285.

2 Passim in the prayers of the namburbi-rituals. 
guide people back into their proper course and to revoke the evil judgment against them. Nevertheless, Ea and Asalluhi, the gods of conjuration and wisdom, must also come to a mortal's aid, as all magical practices for negating a sinister harbinger and for purifying mortals and their homes would surely be to little avail, were not Ea and Asalluhi to lend additional strength to these practices by means of their favour.

Nonetheless, before one could turn to Ea, Šamaš, and Asalluhi for help, one had to prepare oneself with the aid of various purificatory rituals, which sometimes lasted several days. Above all, neither the one being purified nor the conjuror carrying out the ritual was allowed to eat watercress, onions, leeks, or fish (presumably in order not to offend the gods through halitosis).

During the night before the ritual the conjuror prepared the consecrated water which he would need. To do this, he cast all manner of cleansing substances as well as precious stones and metals into a basin filled with water. He then left the basin 'under the stars all night' in order to increase the water's purificatory powers by means of the stars' rays. At dawn the conjuror erected small altars for Ea, Samaš, and Asalluhi by a riverside 'in a place difficult of access'. Previous to this he had cleansed this place by sweeping it and by sprinkling it with consecrated water. Finally, in order to summon and to mollify the gods, he laid out for them an actual meal including bread, meat, dates, incense, water, and various sorts of beer.

Only after the conjuror had requested the gods to 'accept' this offering and had given them enough time to 'consume' their meal was the person whom a sinister omen had threatened allowed to come before the gods to implore them to change the evil fate which they had allotted him. That part of the ritual which now begins is the heart of all 'release rituals', their acme and turning-point. Even if the great gods Ea, Šamaš, and Asalluhi, whom the conjuror had summoned, were not the divinities who had sent the slowly developing punishment in the form of an omen, they had at the very least allowed the person to be burdened with that fate. Only when the person involved had convinced the gods, especially Šamaš, the god of law (kittu) and justice (mišaru), that the impending, evil fate would befall him unjustly, could the sinister power of the harbinger - in our case, the howling dog - be broken. No purification of human beings or their homes would meet with success if the god of justice did not look upon the judgement against them as unjustified or too severe and did not, at the very least, have mercy upon them - even when they had indeed sinned - and grant them forgiveness.

All fears and threats that a person had experienced before the ritual were concretely represented in it by the harbinger, i.e. the howling canine which had come into his house. Either the person affected or the conjuror had to capture the dog before the ritual started or, failing that, to make a clay image of it. This is important from a psychological point of view as well as for the performance of the next part of the ritual: the person's previously diffuse fears regarding his ill-starred future were now visible in the harbinger itself or in its clay image and hence capable of being addressed. The fears had become a concrete object with which one could deal and which one could treat as an opponent while respecting the gods' decision to apportion a bad fate. One thus went before the highest judge Šamaš together with one's opponent, the harbinger or its image, which was formally considered to have the same rights as the person. In none of the preformulated prayers, with which a person in the namburbi rituals entreated Šamaš or $\mathrm{Ea}$ and Asalluhi, is doubt cast upon the correctness and validity of the divine judgement 
which, by means of the evil omen, would bestow an unhappy future upon the affected person. Instead, the affected person attempted to effect a revision of the judgement. A new judgement was then supposed to give him a better fate. Šamaš was asked to effect a revision of the divine judgement. This next part of the ritual is nothing other than a trial in which the affected person as well as his opponent, i.e. the harbinger, appear before the highest divine judge. In this trial, the affected person attempted to renegotiate the gods' disadvantageous decision regarding his future, a decision which had to a certain degree legally empowered the harbinger to bring harm upon him. This decision was now to be reconsidered and corrected in favour of the person affected, even before he could receive any recognisable injury. The harbinger on the other hand was to be condemned and thereupon destroyed.

The ritual before Šamaš is a regular trial with all the elements of an earthly one, the only difference being that the Sun God plays the part of the judge, whereas the person and the harbinger are the two suitors. Ea and Asalluhi function as members of the judicial college. There is no appeal beyond the decision of this court; no one, not even another god, can challenge or alter Šamaš's judgement once rendered. Even the person's household gods, who may have sent the evil in the form of a harbinger in the first place, must defer to this judgement. We see this clearly stated in a prayer to Šamaš, which in a namburbi ritual is addressed against the evil which lizards have announced and transmitted:

Šamaš, great Lord, ..., exalted judge whose sentence is irrevocable, whose 'Yea' no other god can alter, ... Lord, thou art truly great, thy word, thy sentence cannot be forgotten; praying to thee is comparable to nothing; thy sentence is exalted like (unto that of) Anu, thy father; amongst the gods, thy brethren, is thy word the most precious. ${ }^{3}$

As noted above, the person and the harbinger (perhaps in the form of a clay image) come - as in an earthly trial - as suitors before the judge who is to render judgement. The person must seize the harbinger, which threatens his future, with his hands and lift it up in accusation before the divine judge, who was present probably in the guise of an image and obviously in the form of the rising sun. We may safely assume that one faced eastwards when bringing one's case before Šamaš, even if this is not made explicit in any ritual known to the author. The gesture of lifting up the harbinger in the ritual corresponds to the accusation formulated against the harbinger in a prayer to the Sun God: (inalaššu) lumun X palhāku adrāku u šutādurāku. ${ }^{4}$ In many 'release rituals' the person affected, even while he is addressing a prayer, generally thrice repeated, for a revision of his fate to Šamaš, must hold up the image of the harbinger in front of the divine judge. In other rituals either he or the conjuror must bring the harbinger before Šamaš and set him down on the ground 'next to the ritual arrangement to the left'.

When the person, whom the gods had condemned, came before Šamaš, the divine judge, and stood or knelt beside the harbinger and asked for a correction of impending ill-fate, good care was understandably taken to see to it that the displeasure of the gods

\footnotetext{
${ }^{3}$ K 3365 and Duplicate. 11. $25^{\prime}$ ff. (cf. Maul, Zukunftsbewältigung, 307).

4 'Because of the evil which proceeds from X, I am afraid, I fear, and am in anguish' (passim in namburbirituals in prayers to Šamašs, as well as to Šamaš in conjunction with Ea and Asalluhi).
} 
was not again aroused. The person, of whom evil (lumnu) had already taken possession, carried guilt and malignant emanations. But under no circumstances may he again insult the gods by befouling the hallowed ground upon which they had taken their meal and upon which they were supposed to render judgement anew. For the trial $(d i n u)$ the person had to approach the sanctified spot from behind the small altar of the god. He was not allowed to touch the previously purified earth, but was led by the conjuror before Šamaš onto a carpet of 'garden herbs' ( $\check{s} a m m \bar{u}$ kirî) strewn behind the altar. For this carpet one generally used the leaves of the tamarisk tree (binu), the date palm (gišimmaru), and the 'soap-weed' (maštakal), to all of which a cleansing effect was ascribed. Now the carpet did not have the function of keeping one's impurity away from the gods, but served rather the purpose of channelling one's impurity into the ground after the merciful Sun God had rendered judgement. The image of the harbinger, however, was laid unprotected upon the ground before Šamaš. In some rituals it was even set down on pigs' dung so that it would with absolute certainty provoke the god to wrath. On occasion the supplicant supported his claim by means of a bribe: he placed a ransom (iptiru) in the form of gold and other presents at the feet of the divine judge. As a general rule, however, the person involved did not come alone before the god. Instead, the conjuror took him by the hand and, as an intermediary between man and god, went together with him before Šamaš. The prayer to Šamaš which now followed and which contained the plea to reopen the case (ana dinìy a qülamma; dīni dīn) and to release the person from his impending fate was first spoken by the conjuror in the first person and in the stead of the person involved. This person was then required to repeat after the conjuror. The introduction of this person through his intercessor and barrister, the conjuror, corresponds to the socalled scene of introduction on numerous seal impressions from both the Ur III period and Old Babylonian times. The introduction of the supplicant through an intermediary is certainly taken from court ceremony. It is an unspoken assumption in the 'release rituals' that Šamaš after the end of the prayer will 'smile amicably' on the supplicant and, as supreme judge, will accede to the correction of the fate of the person involved. In many rituals, the person affected again addressed prayers separately to Ea and Asalluhi, whose aid was necessary for the succes of the following purification ritual.

Once the favour of the gods had been secured through sacrifice and prayer, the conjuror could proceed with the elimination of the impurity which had arisen through the appearance of the omen. In many rituals the conjuror shattered a clay pot before the eyes of the affected person. This symbolic act must have made a deep impression on the person involved, since it had its 'Sitz im Leben' not only in the rituals but also in profane jurisprudence. In manumissions of slaves for example this act had the function of emphasising that the enslavement had been terminated, that is to say, had been smashed. ${ }^{5}$ In the namburbi rituals the smashing of the pot emphasises that the impurity as well as the threat to the person had now come to an end. Now the person washed himself with the consecrated water which had been prepared during the preceding night. This water removed the impurity, which was thought of as a fine film of dirt, from the body. The dirty water was then poured out upon the figure of the harbinger, standing next to the person, so that the impurity, which had leapt from the howling dog (or another

\footnotetext{
5 Cf. the comments of M. Malul, Studies in Mesopotamian Legal Symbolism (AOAT 221; Kevelaar/NeukirchenVluyn, 1988), 51-69 and 74-76.
} 
object) to the person, now came back to the harbinger itself. In a ritual against a calamity announced by a badger the person spoke the following words while pouring the water onto the figurine of the badger: 'May the calamity emanating from you seize fast upon you yourself!'.

In numerous symbolic actions which now follow, the person received demonstrations of the release from the threat made by the evil omen. For example, he was supposed to strip off the coat he had been wearing and to cut the hair on his head and cheeks. The hair and nails which had grown in the time since his infection by the evil omen represented his status as one against whom the gods had rendered judgement. For this reason the tips of his hair as well as his fingernails, which after a fashion carried the impurity within themselves, had to disappear. Sometimes the person was supposed to peel an onion or unwind a wound thread in order to demonstrate concretely the dissolution of his difficulties.

A further highlight of the ritual was the elimination of the harbinger, which had, as we have seen, come before Šamaš together with the person involved. Notwithstanding the fact that the impurity had been cast back upon the figurine, it still was not accounted as sentenced according to the spirit of the trial before Šamaš described above. Its guilt had first to be proved. In this aspect as well, the ritual follows legal principles from profane jurisprudence. In the same way as the person who stood accused of witchcraft in the absence of legally valid evidence was required by the famed second paragraph of King Hammurapi's Law Code 'to go to the river(-god) and to dive into the river(-god)', so was the harbinger or, rather, its clay image compelled to undergo a river ordeal. From this we may conclude that in the course of the appellate procedure before Šamaš, the harbinger was in some way accused by the affected person of witchcraft. According to the rule in Hammurapi's Law Code the guilt of the accused was proved if he were cast into the river and sank.

In the section of the ritual which now follows the conjuror went with his client to the riverbank. In order to secure the good-will of the river, one first gave him an offering. Beer, flour, and bread were cast into the water and a prayer was addressed to the river. In the ritual against the calamity announced by a howling dog we read: 'Thou, $\mathrm{O}$ river, ... draw that dog down into the apsû. Thou shalt not let it go, draw it down into thy apsû. Rip the calamity emanating from the dog out of my body!'. ${ }^{6}$ Then the conjuror hurled the figure of the dog or harbinger into the river. Since the clay figurine would certainly sink beneath the waves, the guilt of the harbinger was proved and the source of the evil threatening the person banished. The person could now return home secure in the knowledge that his impending fate had legally and with the consent of the gods been taken from him. In not a few rituals the person, before he went home, was supposed to go into an inn and converse with those 'who speak there'. The sage advice to send the affected person into a tavern can only be interpreted as an attempt on the part of the conjuror to reintroduce the person to 'normal', 'intact' society and to encourage him to enjoy life again. Before the person could go into his house again, the impurity spread about there by the harbinger had to be eliminated in numerous purification rituals. On his way home the person had to take good care that he not take the same path by which he had in an unclean state come to the place of judgement, so that he not reinfect himself

${ }_{6}$ Cf. Maul, Zukunftsbewältigung, 318-319. 
with his own footprints. Often he had to wear an amulet for three or seven additional days, an amulet which promised him protection from further evil emanating from an harbinger.

Namburbi rituals were written for hundreds of different evil omens. The Assyrian king Assurbanipal had a complete edition of these texts made for his library. From the colophons of such tablets we know that this series contained at least 135 tablets. The series 'NAM.BÚR.BI.MEŠ' accordingly ranks amongst the longest series ever assembled on clay tablets. Granted, Assurbanipal's interest in this series was not of a literary nature. With this gargantuan series he probably wanted to have an effective weapon against every omen imaginable.

Thanks to the preserved royal corresponce from Nineveh we know that Assurbanipal and his father Esarhaddon employed several independent teams of conjurors, scribes, and astrologers who were supposed to observe the heavens and also to write down any unusual occurrences of whatever nature. They had to promptly report these to the king so that enough time remained to prepare and carry out a 'release ritual' before the calamity had a chance to crystallize. For just this purpose an entire staff of conjurors - organised almost like a ministry - stood ready, a staff that pored over collections of omens for the purposes of diagnosing a portent, that put rituals together, and that carried them out. Believing that he had already eliminated all possible future evil before it could even take shape surely bolstered the king's self-confidence, strengthened his resolution, and steeled his will to fight. In this sense 'release rituals' were by no means a hindrance born of superstition. Instead, they were a stabilising factor in the history of the Assyrian Empire. 